\title{
Modeling Gloss Control in Polyester/ $\beta$-Hydroxyalkylamide Powder Coatings Based on SPM Structure-Property Relationships
}

\author{
Louis T. Germinario* and Damiano Beccaria ${ }^{* *}$ \\ *Eastman Chemical Company, Global Polymers \& Research Analytical Services, Kingsport, TN, \\ 37662 \\ ** Eastman Chemical Company, European Technical Center, Via Morozzo 27 Sant'Albano, Sutura \\ 12040 , Italy
}

Many applications in powder coatings required specified and reproducible optical properties, such as gloss control, in addition to mechanical toughness and durability. A formulation strategy will be described for achieving consistent low gloss levels using six different dry blended polyester resins and different ratios of $\beta$-Hydroxyalkylamide ( $\beta$-HAA) crosslinking agent. Scanning probe microscopy (SPM) provided a comprehensive approach to measure surface topography, surface roughness, as well as, characterization of surface stiffness and microhardness. These structureproperty relationships were used to develop models that could be employed by coatings formulators for predicting and achieving specific gloss values, for a specified price and performance.

Dry blending of incompatible powder coatings formulations has been the standard way for achieving controlled gloss using tri-glycidyl isocyanurate (TGIC) as the high temperature-curing agent. However, due to regulatory concerns over mutagenicity of TGIC systems, $\beta$-HAA has proven to be a useful alternative. Owing to a paucity of data on $\beta$-HAA cured low gloss formulations, the focus of this paper is to report recent developments of polyester- $\beta$-HAA formulations using dry blends made from coatings of differing reactivities, viscosity, and acid values (AV), Table 1, [1,2].

In this work, a number of white coating formulations were prepared using resins that had been specifically designed for $\beta$-HAA cure. It was expected, based on experience with TGIC systems, that the variations in gel times and acid values would afford the ability to achieve desired variations in gloss. Force modulation proved to be a very useful imaging mode for mapping topography and differences in surface stiffness, Figure 1, for the various formulations. These data provide some direct evidence for a concentration effect of curative on a coating's surface roughness and stiffness. These data also show that as the amount of $\beta$-HAA is increased, for Resin 3-Resin 6 system, to $6.75 \%$, and cured for 10 minutes at $200^{\circ} \mathrm{C}$, there is a significant increase in surface roughness, as well as, an increase is surface stiffness, when compared to (Resin 1/Resin 4) system containing $3.75 \%$ of $\beta$-HAA (Table 2 ). These data support the hypothesis that higher $\beta$-HAA levels lead to an increase in both surface roughness and stiffness. Multivariate correlations are also discussed which provide a link between gloss, surface roughness, force modulation, \% $\beta$-HAA and a coating's impact properties.

[1]. The commercial names for polyester resins indicated in Table 1 are included in Annex I.

[2]. Presented at the International Waterborne, High-Solids, and Powder Coatings Symposium, Feb.

26-28, 2003, New Orleans, LA, USA 
Table 1. Resin Properties

\begin{tabular}{|c|c|c|c|c|}
\hline & $\begin{array}{c}(\mathrm{AV}) \\
\mathrm{mg} \mathrm{KOH}\end{array}$ & $\begin{array}{c}\text { Viscosity } 200^{\circ} \mathrm{C} \\
\text { mPa.s }\end{array}$ & $\begin{array}{l}\text { Tg } \\
{ }^{\circ} \mathbf{C}\end{array}$ & $\begin{array}{c}\text { Gel Time } 180^{\circ} \mathrm{C} \\
\text { Minutes }\end{array}$ \\
\hline Resin 1 & 16 & 6300 & 50 & 6’30”' \\
\hline Resin 2 & 20 & 6000 & 60 & 4'15' \\
\hline Resin 3 & 25 & 5100 & 59 & 3'15" \\
\hline Resin 4 & 35 & 3400 & 60 & 2’20”' \\
\hline Resin 5 & 49 & 3800 & 67 & 1'30' \\
\hline Resin 6 & 73 & 2400 & 54 & 2’00”' \\
\hline
\end{tabular}
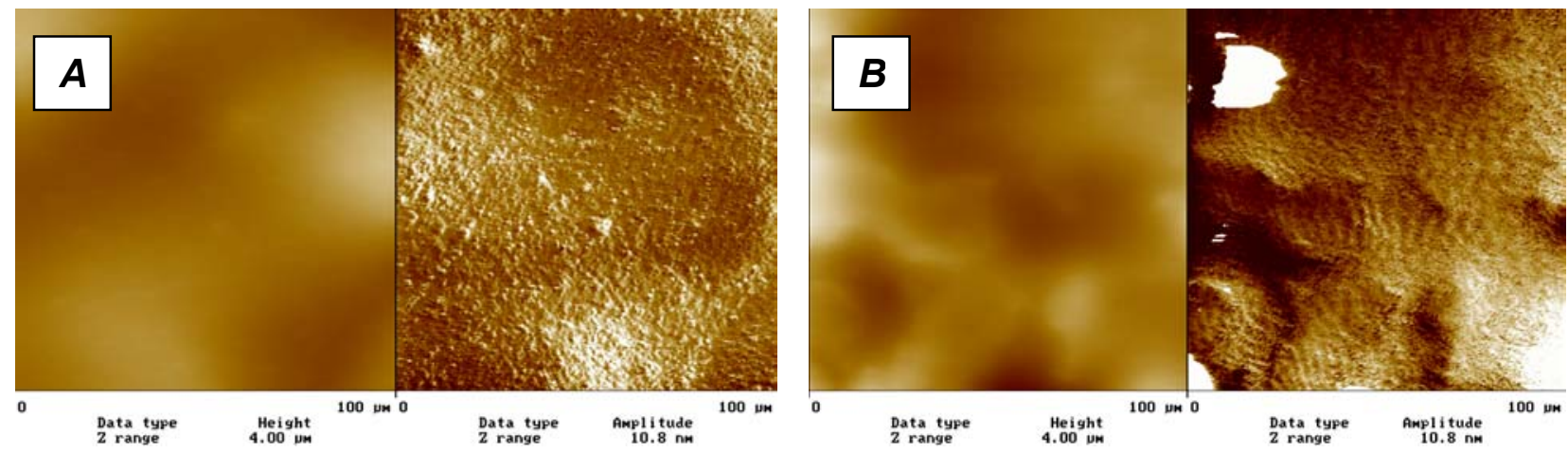

Figure 1. Height Image and Force Modulation Image of (A) Resin 1-Resin 4 White coatings $(\mathrm{RMS}=0.44 \mu$ Avg. RMS Force Mod $=1.86 \mathrm{~nm})$ and $(B)$ Resin 3-Resin 6 White coatings $(\mathrm{RMS}=0.72 \mu$ Avg. $\mathrm{RMS}$ Force $\operatorname{Mod}=6.13 \mathrm{~nm})$

Table 2: White Coating Results

\begin{tabular}{|l|c|c|c|c|c|c|c||}
\hline $\begin{array}{l}\text { Dry- } \\
\text { Blends }\end{array}$ & $\begin{array}{c}\text { Cure } \\
\text { conditions }\end{array}$ & Gloss 60 & $\begin{array}{c}\text { Direct } \\
\text { Impact }\end{array}$ & $\begin{array}{c}\text { Reverse } \\
\text { Impact }\end{array}$ & $\begin{array}{c}\text { RMS } \\
\text { (micron) }\end{array}$ & $\begin{array}{c}\text { Force Mod } \\
\text { RMS (nm) }\end{array}$ & $\begin{array}{c}\text { \% } \beta-H A A \\
\text { in blend }\end{array}$ \\
\hline $\begin{array}{l}\text { Resin 3: } \\
\text { Resin 6 }\end{array}$ & $10^{\prime} \times 200^{\circ} \mathrm{C}$ & 25 & 60 & 30 & 0.72 & 6.13 & 6.75 \\
\hline $\begin{array}{l}\text { Resin 2: } \\
\text { Resin 6 }\end{array}$ & $10^{\prime} \times 200^{\circ} \mathrm{C}$ & 20 & 40 & 20 & 0.77 & 3.60 & 6.50 \\
\hline $\begin{array}{l}\text { Resin 2: } \\
\text { Resin 5 }\end{array}$ & $10^{\prime} \times 200^{\circ} \mathrm{C}$ & 34 & 120 & 120 & 0.49 & 2.67 & 5.00 \\
\hline $\begin{array}{l}\text { Resin 1: } \\
\text { Resin 5 }\end{array}$ & $10^{\prime} \times 200^{\circ} \mathrm{C}$ & 25 & 160 & 140 & 0.65 & 4.05 & 4.75 \\
\hline $\begin{array}{l}\text { Resin 1: } \\
\text { Resin 4 }\end{array}$ & $10^{\prime} \times 200^{\circ} \mathrm{C}$ & 38 & 160 & 160 & 0.44 & 1.86 & 3.75 \\
\hline
\end{tabular}

\section{Annex I:}

Resins 1,2,3,4,5,6 are Albester resins: 5600, 5540, 5501, 5550, 5590, and 5580, respectively. 